\title{
Player's value, field performance, financial performance and stock performance of European football clubs
}

\author{
M.R.W. Putra \& G.H. Wasistha \\ Department of Accounting, Faculty of Economics and Business, Universitas Indonesia, Depok, Indonesia
}

\begin{abstract}
The purpose of this research is to analyse the relationship between a player's value, field performance, financial performance and stock performance of European football clubs. The samples used in this research consist of 17 European football clubs listed in the stock exchange. The method used to analyse the data is the Generalized Structural Component Analysis (GSCA). The results show that, firstly, a player's value has a positive impact on a club's financial performance, but its impact on field performance is insignificant. Secondly, field performance and financial performance have a significant impact on each other. Finally, both field performance and financial performance do not have a significant impact on a football club's stock performance.
\end{abstract}

\section{INTRODUCTION}

In this century, football has entered a new industrial level, especially in Europe. The revenue of the 237 clubs participating in European competition has been rising by $9.9 \%$ season by season, standing at EUR 8.1 billion. For the biggest 25 clubs, the growth is even more staggering, showing a 41.9\% rise from season 2009/2010 to season 2013/2014 (UEFA, 2015a). The driving force behind this revenue growth is the increase in television rights, sponsorship money and merchandise sales (UEFA, 2015b).

However, along with the increase in revenue, players' transfer prices and wages are also inflated. Tomkins (2015) states that the inflation rate of players' transfer prices exceeds the average inflation level in the United Kingdom. Furthermore, Rikardsson and Rikardsson (2013) state that the wage bill level is now at $60-80 \%$ of club revenue. Football clubs are more susceptible to bankruptcy as they react more to negative shocks (Szymanski, 2012).

Aside from being susceptible to bankruptcy, owning a football club is perceived as a losing investment, particularly with regards to its stock. Evidence for this is the continual decrease of the stock value of Italian clubs on the Milan Stock Exchange (Dragoni, 2014).

This research aims to evaluate these phenomena by explaining the impact of a player's value on the financial performance and field performance of the club, as well as the effect of such performances on the club's stock performance.

The results will be useful for club managers and investors. For Indonesia, the results of this paper will be useful to plan the national football landscape. After a series of bad experiences from 2013 to 2016, Indonesian football is still looking for a way to recover. The rising costs, the bankruptcy phenomenon and the losing investment paradigm among European football clubs can be avoided in Indonesia if a proper plan is applied.

\section{LITERATURE REVIEW}

The indicators for players' values are the wages and players' registration rights. Szymanski and Smith (1997) use players' wages as the indicator of the value of such players. Clubs pay their players according to their ability and, therefore, players' wages reflect their value. 
The value of a player's registration rights is derived from the player's transfer value. The latter is widely used in European football since the adoption of the Financial Reporting Standard (FRS) 10 - Goodwill and Intangible asset by the Union of European Football Associations (UEFA). FRS 10 requires that a player's transfer value is capitalised as an intangible asset.

Specifically, football clubs' performance measurement can be seen from two aspects, namely field and financial performances (Samagaio et al., 2009). Field performance can be measured by a simple measure, such as their league position at the end of the season, or by more complex indicators, such as the one developed by Barajas et al. (2005). Barajas et al. (2005) developed a new coefficient formula to incorporate clubs' performances in all competitions. Financial performance can also be measured by a simple indicator, such as revenue, or more complex indicators, such as the financial ratio.

Early research on a player's value in relation to the club's field performance and financial performance was done by Szymanski and Smith (1997). The result shows that a player's value has a positive impact on field performance and, in turn, field performance has a positive impact on financial performance. Kase et al. (2006) concluded that financial performance has a positive impact on long-term field performance. Samagaio et al. (2009) found that a player's value has no impact on field performance, but confirm that there is an impact on financial performance.

It is expected that a player's value will give a boost to both the field and financial performance of the club. Star players with high wages, such as Cristiano Ronaldo and Lionel Messi, can change the course of the game. Clubs can also benefit from an increase in television rights, gate receipts and merchandise sales if they have star players.

Szymanski and Smith (1997) and Samagaio et al. (2009) support the claim that field performance has a positive impact on financial performance. It is expected that clubs with a better field performance will make higher revenue from competition prizes, television rights and gate receipts.

H1. Player's value has a positive impact on field performance.

$\mathrm{H} 2$. Player's value has a positive impact on financial performance.

Both Kase et al. (2006) and Samagaio et al. (2009) support the claim that financial performance has a positive impact on field performance. A club needs to have a healthy financial position in order to build a strong squad and pay their expenses. A club with an unhealthy financial position will find it difficult to survive among the competition and ultimately may end up bankrupt if they fail to settle their liabilities.

H3. Financial performance has a positive impact on field performance.

H4. Field performance has a positive impact on financial performance.

Regarding football clubs' stock, Renneboog and Vanbrabant (2000) state that field performance has a positive impact on stock performance. This result is further supported by Floros (2014). Renneboog and Vanbrabant (2000) also add that financial performance has a positive impact on stock performance. Only Samagaio et al. (2009) conclude that both field performance and financial performance have no significant impact on stock performance.

H5. Financial performance has a positive impact on stock performance.

H6. Field performance has a positive impact on stock performance.

\section{RESEARCH METHOD}

Quant/qual/Mixed-method? Pimary/Secondary Data? Population? Sampling Technique? This research uses a sample of 17 European football clubs that are actively listed on the stock exchange. The data were collected using the Eikon Database for financial report data, Yahoo! Finance for stock related data and www.statto.com for field performance related data. The model used in this research is based on the model proposed by Samagaio et al. (2009) with some modifications. The player's value is added into a separate, observed variable, while field performance (FIELD) indicators are modified into indicators developed by Barajas et al. (2005). 
Figure 1 gives an overview of the research model.

Table 1 gives a short explanation of the latent variables used in the model:

Data for variables W/S, INT, TNV, OOC, NPP and NI are taken directly from the clubs' financial reports. The FIELD variable is measured by indicators developed by Barajas et al. (2005). This variable is measured by the total number of points achieved in the domestic league (DOM), domestic cup (CUP) and UEFA Champions League (CL) or EURO Cup/ Europa League (EUR). For the cup format tournament (DOM, CL and EUR), the coefficient is calculated as shown in Table 2:

To combine all the variables into a single field performance indicator, Barajas et al. (2005) assign a weight to each variable as shown in Equation 1:

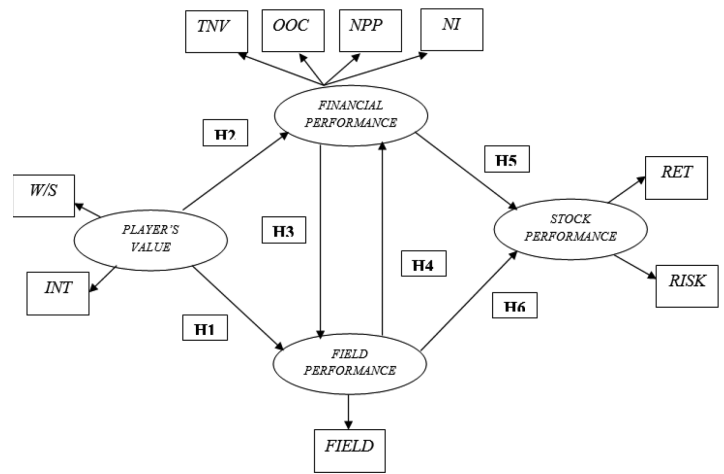

Figure 1. Initial research model.

Table 1. Short explanation of latent variables.

\begin{tabular}{ll}
\hline Variable & Short explanation \\
\hline$W / S$ & Wages and Salaries \\
$I N T$ & Player's Contract Rights Registration \\
$T N V$ & Turnover \\
$O O C$ & Other Operating Expenses \\
$N P P$ & Net Profit from Sales of Player's Rights Registration \\
$N I$ & Net Income \\
FIELD & Field Performance Indicator as developed by Barajas et al. (2005) \\
RET & Stock Return \\
RISK & Stock Risk \\
\hline
\end{tabular}

Table 2. Cup format coefficient according to Barajas et al. (2005).

\begin{tabular}{ll}
\hline Achievement & Coefficient \\
\hline Champion & 39 \\
Runner-up & 33 \\
Semi-final & 27 \\
Quarter-final & 21 \\
Round 16 & 15 \\
Round 32 & 9 \\
Round 64 & 6 \\
Round 128 & 3 \\
< Round 128 & 0 \\
\hline
\end{tabular}




$$
\mathrm{FIELD}=3 \cdot \mathrm{CL}+2 \cdot \mathrm{EUR}+2 \cdot \mathrm{DOM}+\mathrm{CUP}
$$

Next, RISK is measured by the daily stock return $(R E T)$ standard deviation, where $R E T$ is defined as shown in Equation 2:

$$
\text { DailyStock Return }(\text { RET })=\ln \left(\frac{\text { StockValueatt }}{\text { StockValueat }-1}\right) \times 100
$$

The data will be analysed using the Generalized Structured Component Analysis (GSCA) with the Alternate Least Square (ALS) method. GSCA is used because of its advantage in analysing data with a few samples (Hwang \& Takane, 2004).

The structural model used in this research is:

$$
\gamma=B^{\prime} \gamma+\xi
$$

The measurement model used in this research is:

$$
\begin{aligned}
& Z=C^{\prime} \gamma+\varepsilon \\
& Z \xi 1=\gamma 1 C i+i \text { if } i \leq 2 \\
& Z \xi 1=\gamma 3 C i+i \text { if } i=3 \\
& Z \xi 1=\gamma 3 C i+i \text { if } i=4 \\
& Z \xi 1=\gamma 4 C i+i \text { if } i=5
\end{aligned}
$$

Z: Standardised Indicators Variable's Matrix

C: Loading Matrix between Latent Variables and Indicators

B: Path Coefficient Matrix that connects Latent Variables

$\varepsilon$ : Residual Vector

$\gamma$. Latent Variable Vector

$\xi$ : Residual Vector for $\gamma$

i: Amount of Indicators Variable

\section{RESULTS}

The initial model was modified in order to pass the data reliability test. The modified model was developed by selecting only a single indicator to measure financial performance and stock performance. Based on Szymanski and Smith (1997), financial performance is measured solely by revenue, while according to Renneboog and Vanbrabant (2000), stock performance is measured solely by stock returns.

The results as presented in Table 3 show that 3 out of the 6 hypotheses are accepted. Consistent with the hypotheses, a player's value has a positive impact on the club's financial performance. Financial performance has a positive impact on field performance. Field performance also has a positive impact on financial performance. The analysis will be provided in the next section.

Table 3. Hypothesis testing results.

\begin{tabular}{llll}
\hline Hypothesis testing variable & Estimate & SE & CR \\
\hline Player's Value $\rightarrow$ Financial Performance & 0.858 & 0.035 & $24.38^{* *}$ \\
Player's Value $\rightarrow$ Field Performance & 0.149 & 0.133 & 1.12 \\
Financial Performance $\rightarrow$ Field Performance & 0.350 & 0.124 & $2.83^{* *}$ \\
Financial Performance $\rightarrow$ Stock Performance & 0.049 & 0.058 & 0.85 \\
Field Performance $\rightarrow$ Financial Performance & 0.086 & 0.039 & $2.23^{* *}$ \\
Field Performance $\rightarrow$ Stock Performance & 0.057 & 0.083 & 0.68 \\
\hline
\end{tabular}

**: Significant at 0.05 level. 


\section{DISCUSSION}

A player's value has no significant effect on the club's field performance. This implies that clubs cannot rely solely on the value of their players to achieve good results on the field. This is consistent with Samagaio et al. (2009). For example, in the 2015/2016 season of the English Premier League, out of the 7 clubs with the highest wage bills, 3 of them finished at the bottom of the table. One of them, Newcastle United, was relegated. On the other hand, Leicester City, ranked only 17th in wage expenditure (Horsefield, 2015), came out on top at the end of the 2015/2016 season.

Clubs can use their scouting network and academy to enhance their field performance without relying on a player's value. Di Minin et al. (2014) found that the good use of both their scouting network and the club's academy had a significant impact on Udinese's success. Bigger clubs can also benefit from this. For example, Barcelona got their best player, Lionel Andres Messi, from their scouting network in Argentina, and nurtured him in their reputable La Masia academy.

Other big clubs are following in the footsteps of FC Barcelona, for example, Manchester City. Until now, the club, which is also known as "The Citizens", has spent much more than most European clubs. However, they have also equipped themselves with a better club academy. Manchester City hired former FC Barcelona Sporting Director Txiki Begiristain and began the project to build their own "La Masia". Now promising young stars, such as Denis Suarez and Kelechi Iheanacho, have emerged after completing several years training in Manchester City's academy.

The next result shows that a player's value has a positive effect on the club's financial performance. This implies that clubs can get additional revenue by acquiring highly paid star players. The revenue comes from sales of merchandise, sponsors and additional match coverage on television. However, due to the proneness of football clubs to negative shocks (Szymanski, 2012), they have to consider their financial condition when acquiring highly paid players.

This result also marks the shift in the business model of football clubs. Clubs are gradually shifting from the SSSL (Spectator, Sponsorship, Subsidies and Local) model to the MCMM (Media, Corporate, Merchandise and Market) model. The SSSL model relies heavily on ticket sales, sponsorship and funds from the government and local communities as sources of revenue. On the other hand, the MCMM model relies more on television rights, sales of image rights and sales of merchandise. The example of this is Real Madrid. Under the stewardship of Florentino Perez, Los Blancos transformed itself into a Galactico, a club filled with superstar players. The result has been successful. For 12 consecutive years since 2004, Real Madrid topped the Deloitte Money League Chart as the club with the biggest revenue.

For clubs that are smaller than the likes of Real Madrid or Manchester United, acquiring highly paid star players can still be useful. However, they need to be mindful of their financial condition in order to avoid financial distress.

Financial performance has a positive impact on a club's field performance. This is consistent with Kase et al. (2006) and Samagaio et al. (2009). Kase et al. (2006) emphasises that a club's financial health has a significant impact on their long-term field performance. This implies that clubs cannot sacrifice their financial health for the sake of short-term success if they want to survive in the long term.

Manchester United and Real Madrid set examples for this. Their current success is because of their careful financial management. Both Real Madrid and Manchester United had set themselves up to be a global brand as early as the late $1990 \mathrm{~s}$ under the leadership of the clubs' respective directors and presidents.

Establishing the club's financial security and winning trophies should be done simultaneously. Under spending can lead to underperformance, as the club will not be able to fortify its squad with strong players. This problem can be solved by careful transfer management and by using an extensive scouting network and having an excellent academy.

On the other hand, overspending can lead to financial distress, despite winning trophies. The Milan duo, AC Milan and Internazionale Milan, are prime examples of clubs whose 
financial condition declined significantly shortly after winning trophies (Bandini, 2015). Both clubs failed to qualify for the UEFA Champions League from season 2013/2014 to season 2015/2016, less than 5 years after they won the Italian Serie A.

The next result shows that a club's field performance has a positive impact on their financial performance. This implies that a club's good performance brings them more revenue. This is consistent with the results of Szymanski and Smith (1997) and Samagaio et al. (2009). Successful clubs can benefit from more gate receipts, television rights and merchandise sales revenue. For example, Juventus received EUR 80 million from television rights in the 2014/2015 season, EUR 50 million of which came from their participation in the 2014/2015 UEFA Champions League final. Clubs play more home matches as they progress into the later stages of the competition. Therefore, it is logical that they get more revenue from gate receipts.

It is natural that clubs want the best results on the field. However, as they cannot rely on their players' value, alternatives have to be made. For example, clubs can use the human resource management approach by motivating players through other means than money. Mathis and Jackson (2011) state that employees' satisfaction comes through psychological factors rather than monetary factors. In football, players' job satisfaction is very important because they are the core of the business.

UEFA attempted to solve the problems related to the financial condition of the clubs. They came up with the Financial Fair Play (FFP) rules. However, the implementation of these rules has not been entirely successful, as clubs can still manage to overspend (Gibson, 2015). Two cases in point are Manchester City and Galatasaray. Manchester City's squad players were reduced to $21 \mathrm{men}$, and the club had to pay a GBP 42 million fine in 2015. One year later, Galatasaray had to serve a one-year ban from European competition due to their violation of the Financial Fair Play rules. So far, the FFP rules have not stopped clubs from overspending.

An alternative to the FFP rules can be found in American sports. According to Totty and Owens (2011), the salary cap implemented in American sports has successfully increased the leagues' competitiveness and ensured the clubs' financial health. For example, in the NBA and NFL, due to the salary cap, no clubs are in danger of insolvency, and the league remains competitive. However, the implementation of a salary cap in football may find opposition from the big clubs.

The last result shows that a club's stock performance is not affected by either their financial or field performance. This is consistent with the findings of Samagaio et al. (2009). This result implies that investors cannot rely solely on clubs' financial or field performances to make an investment decision., and therefore the effect is not significant. Another explanation is that investors are irrational. That is, their investment decision is based on their fanatical support towards the club. Such investors do not care whether their club is winning or losing. They also do not care whether the club's financial report is healthy or not, or whether it records any profit or not. They are just proud that they own a part of their favourite football club.

Other indicators, such as squad harmony, clubs' transfer and management policies and clubs' investment decisions, may affect clubs' stock performance. Therefore, investors are advised to consider not only the field and financial performances in their investment decisions but also these other factors.

\section{CONCLUSION AND RECOMMENDATIONS}

This paper concludes that a player's value has a positive impact on the club's financial performance but has no significant impact on field performance. Next, field performance has a positive impact on financial performance, and financial performance also has a positive impact on field performance. Lastly, neither financial performance nor field performance has a significant effect on a football club's stock performance. So? What are the implications then? 
For the football club managers, it is recommended that they use an extensive scouting network and maximise the club's academy to enhance field performance. The signing of highly paid star players is encouraged as a means to increase revenue, as long as it does not affect the club's financial balance. In addition, managers should balance their field performance target with the club's financial health. To enhance field performance without further burdening the club's financial condition, managers can use a psychological approach instead of a monetary approach with the players.

For investors, as field performance and financial performance are not enough to make investment decisions on a football club's stock, they should also consider other indicators. Those indicators are squad harmony and the club's transfer and managerial policies.

\section{LIMITATIONS}

This paper has several limitations, which are:

- It only has a small number of samples. Unfortunately, this limitation cannot soon be overcome due to the small number of listed football clubs.

- The measurement for a player's value still excludes the fair value of players. The measurement of academy graduate players, which has no value on current accounting standards and the fair value of transfer, should be part of the next research.

\section{REFERENCES}

Bandini, P. (2015, January 17). Milan and Internazionale face up to new realities of life in Serie A. The Guardian. https://www.theguardian.com/football/2015/jan/17/milan-internazionale-serie-aitalian-football-city-rivals.

Barajas, A., Fernandez-Jardon, C. \& Crolley, L. (2005). Does sports performance influence revenues and economic results in Spanish football? MPRA Munich Personal RePEc Archive, no. July. http://mpra.ub.uni-muenchen.de/3234/\%5Cnhttp://scholar.google.com.br/citations?view_op=view_ citation\&continue $=/$ scholar?hl=pt-BR\&as_sdt $=0,5 \&$ scilib $=1 \&$ citilm $=1 \&$ citation_for_view $=$ X718wt4 AAAAJ:AvfA0Oy_GE0C\&hl=pt-BR\&oi=p.

Di Minin, A., Frattini, F., Bianchi, M., Bortoluzzi, G. \& Piccaluga, A. (2014). Udinese Calcio soccer club as a talents factory: Strategic agility, diverging objectives, and resource constraints. European Management Journal, 32(2), 319-36. doi:10.1016/j.emj.2013.04.001.

Dragoni, G. (2014, December 31). Investing in a football team is not a good deal: In 2014 all three clubs Listed in Milan lost value. Italy Europe 24:Il Sole 24 Ore Digital Edition. http://www.italy24.ilsole24ore.com/art/panorama/2014-12-30/investing-a-football-team-is-not-good-deal-2014-all-threeclubs-listed-milan-lost-value-202426.php?uuid=ABj8h9WC.

Floros, C. (2014). Football and stock returns: New evidence. Procedia Economics and Finance, 14, 201209. doi:10.1016/S2212-5671(14)00703-5.

Gibson, O. (2015). Financial fair play: How can Manchester City still spend $£ 130 \mathrm{~m}$ in one window? The Guardian.https://www.theguardian.com/football/blog/2015/sep/02/financial-fair-play-manchester-city.

Horsefield, I. (2015). Every Premier League club's wage bill revealed: So who spends the most on their players? Express. http://www.express.co.uk/sport/football/656624/Pictures-Premier -League-club-wage-bill-revealed.

Hwang, H. \& Takane, Y. (2004). Generalized Structured Component Analysis. Psychometrika, 69(1), 81-99. doi: 10.1007/BF02295841.

Kase, K., Gómez, S., Urrutia, I., Opazo, M. \& Martí, C. (2006). Real Madrid-Barcelona: Business strategy vs. sports strategy, 2000-2006. Occasional Paper, 06/12. http://www.iese.edu/research/pdfs/ op-06-12-e.pdf?q=la-liga-results.

Mathis, R.L. \& Jackson, J.H. (2011). Human resource management: Essential perspectives. Mason, OH, USA: Cengage Learning.

Renneboog, L. \& Vanbrabant, P. (2000). Share price reactions to sporty performances of soccer clubs listed on the London Stock Exchange and the AIM. Center Discussion Paper Tilburg University, 2000-19, 1-31. https://pure.uvt.nl/portal/files/534671/19.pdf. 
Rikardsson, H. \& Rikardsson, L. (2013). Strategic management in football. MA Thesis, Linköping University.

Samagaio, A., Couto, E. \& Caiado, J. (2009). Sporting, financial, and stock market performance in English football: An empirical analysis of structural relationships. Centre for Applied Mathematics and Economics (CEMAPRE) Working Papers. http://cemapre.iseg.utl.pt/archive/preprints/395.pdf.

Szymanski, S. \& Smith, R. (1997). The English football industry: Profit, performance and industrial structure. International Review of Applied Economics, 11(1), 135-53. doi:10.1080/02692179700000008.

Szymanski, S. (2012). Insolvency in English professional football: Irrational exuberance or negative shocks? International Association of Sports Economists Working Paper 1202. http://web.holycross. edu/RePEc/spe/Szymanski_Insolvency.pdf.

Tomkins, P. (2015, August 5). Football inflation and the transfer window. Vice Sports. https://sports.vice. com/en_uk/article/football-inflation-and-the-transfer-window.

Totty, E.S. \& Owens, M.F. (2011). Salary caps and competitive balance in professional sports leagues. Journal for Economic Educators, 11(2), 46-56. http://frank.mtsu.edu/ jee/2011/fall/5_MS1011pp45to56.pdf.

UEFA (Union of European Football Associations). (2015a). UEFA Club Benchmarking Report 20132014 Season. Switzerland: UEFA. http://www.uefa.org/MultimediaFiles/Download/Tech/uefaorg/ General/01/99/91/07/1999107_DOWNLOAD.pdf.

UEFA (Union of European Football Associations). (2015b). UEFA Club Licensing Report 2014: The European Club Footballing Landscape. Switzerland: UEFA. http://www.uefa.org/MultimediaFiles/ Download/Tech/uefaorg/General/02/29/65/84/2296584_DOWNLOAD.pdf. 